\title{
Assessment of Guests' Perception in Implementation of Green Hotel in Supporting Sustainable Tourism
}

\author{
I Gusti Ayu Oka Suryawardani and Agung Suryawan Wiranatha
}

Lecturer at Doctoral Program in Tourism and Researcher at Tourism Research Consortium Udayana University, Bali, Indonesia

Coressponding author: gungdani@gmail.com

\section{ARTICLE INFO}

Received

02 October 2015

Accepted

05 February 2016

Available online

07 March 2016

\section{ABSTRACT}

Tourism industry faced by threats in implementing sustainable tourism development. UNEP (United Nation Environmental Programme) designs the concept to gain sustainable development through the program called the greening of industry which includes minimization of energy used, reducing green house emission, water consumption efficiency, waste management, reducing loss of biological diversity, and preserving cultural heritage. Dependency of tourism industry in using energy will impact in global warming and climate change which will lead to sustainability of the future of tourism development. The research was designed to assess guests' perception on implementation of green hotel in supporting sustainable tourism in Bali.

Research was undertaken in DKP hotel which is located in Kuta, Bali in the periods of April-June 2011. The hotel was choosen because DKP hotel is one of the hotels in Bali that has implemented the concept of green hotel in the hotel operational and was awarded as Green Hotel Award in the year of 2010. Sample was designed based on the minimum criteria on using Structural Equation Modelling (SEM). Respondents were guests who stay in the hotel and were willing to be interviewed and fill-in the questionnaires. The number of respondents were 121. Assessing guests' perception was undertaken based on five-point Likert rating scale and relationship between variables which express level of concern of hotel management on the environment conservation, social-culture preservation and economic development were analyzed by using Software AMOS Version 23.

The results show that assessment of guests' perception in implementation of green hotel in the hotel operational through conservation of environment and preserving social and culture and its impact on economis development was positip and has resulted in supporting sustainable tourism. Environmental conservation awarenesss has been implemented through energy and water efficiency, waste management has been applied by implementing reuse and recycle programs. Social concern has been undertaken through CSR programs.

Keywords: efficiency, conservation, preservation, green tourism, sustainable tourism 


\section{Introduction}

Tourism became a very important driving force in the world economy and is believed to be most likely to raise the welfare of society. Theobald (2005) reveals that based on WTO cites projections that international tourists will increase to 1.6 billion people per year by the year 2020, with a predicted expenditure of more than 2 trillion USD annually. This projection is based on the average growth of the world's travelers of $4.3 \%$ per year, while expenditures stay at $6.7 \%$ per year.

Bali is one of the world's famous tourist destinations because it has a unique culture and natural beauty. As a vehicke of economiec development of Bali, Bali tourism has contributed very significantly to the economic development of Bali (Erawan, 1994). The rapid development of the tourism sector which leads to changes in the economic structure of the region Bali, from an agrocultural economy to services.

Beside the positive impact of tourism, tourism also brings about negative impacts. To minimize the negative impact of tourism, the concept of sustainable tourism is really important to be implemented which refers to environmentally friendly, economically viable and socio-culturally acceptable, and a suitable balance must be established between these three dimensions to guarantee its long-term sustainability. All of those three elements should be coherent with each other to ensure quality as Elkington (1997) says that continuity and balance between the needs of tourism, protection of the environment and prosperity for the local community, which means that the economic benefit of tourism should be beneficial not only for the companies concerned but also for the local communities as the host. The business entity should be used as a vehicle for coordinating stakeholders' interests, instead of maximizing shareholder (owner) profit, so that it can achieve quality, continuity and balance. Good quality, sustainable tourism provides a quality experience for the visitor, while improving the quality of life of the host communities and protecting the quality of the environment. As regards continuity, sustainable tourism ensures the continuity of the natural resources upon which it is based and the continuity of the culture of the host community with satisfying experiences for visitors. Balanced, sustainable tourism balances the needs of the tourism industry, the natural environment and the local communities. Sustainable tourism emphasizes mutual goals and cooperation among visitors, host communities and destination, in contrast to more traditional approaches to tourism which emphasize their diverse and conflicting needs (WTO, 2007).

The role of tourism and the negative impact is always a discourse in realizing sustainable development. On one hand, tourism has a very significant role in improving the economy of the community such as improving the exchange rate, increase income and employment. Tourism is also believed to be one of the industries with huge potential in developing the potential of local communities and alleviate poverty (Fridgen, 1996; Fyall and Garrod, 2005; Mill and Morisson, 2009). Beside positive impact, tourism is convinced as the main contributor for environmental degradation, such as air and waste polutions which will threat sustainability of a destination (Mill and Morisson, 2009).

Tourism industry faced by some threats in implementing sustainable tourism development. UNEP (United Nation Environmental Programme) designs the concept to gain sustainable development through the program called "the greening of industry" which include energy and green house emission, water consumption, waste management, loss of biological diversity, and cultural heritage management. Dependency of tourism industry in using energy will impact in global warming and climate change which will lead to sustainability of the future of tourism development.

\section{Research Objective}

Research was design to study guests' assessment on implementation of green hotel in supporting sustainable tourism in Bali. 


\section{Literature Review}

\section{Green Economy, Green Tourism and Green Hotels}

\section{Green Economy}

The words going green and back to nature have been widely used as an expression for reflection of nature, freshness, preserving and balancing. Since 2006, going green has been booming and has been used to strengthen positioning of products and services to gain the potential market and now is becoming the mindset for everbody and organization all around the world (Mendiratta, 2012).

UNEP (United Nation Environmental Programme) used "The Greening Industry" in designing the concept of sustainable development as reflection of economic development through implementation of low carbon economy in term of reducing carbon emision, increase efficiency in using water and natural resources as well as preventing the existing of diversity. Moreover, the greeing industry is the industries which are focused on avoiding exploitation of the natural resources (UNEP, 2009).

Based on the above definition, it can be understand about three keywords in the concept of green economy, that are low carbon, resources efficiency and socially inclusive. Purpose of green economy are increase in social welfare and quality of life as well as minimization of the impact of development to the environment which threaten ecological diversity of flora and fauna and enable to increase the quality life of human being (UNEP, 2011).

“....a green economy as one that results in improved human well-being and social equity, while significantly reducing environmental risks and ecological scarcities. In its simplest expression, a green economy can be thought of as one which is low carbon, resource efficient and socially inclusive..." (UNEP, 2011:416).

Moreover, Lipman (2011) says that:

“... a green economy is one whose growth in income and employment is driven by public and private investments that reduce carbon emissions and pollution, enhance energy and

http://ojs.unud.ac.id/index.php/eot resource efficiency, and prevent the loss of biodiversity and ecosystem services ..." (Lipman, 2011:28)

It can be said that geen economy is economic development which is based on the ecological sound to make a coherence relationship between economic benefit and environmental protection in order to enhance sustainable development.

\section{Green tourism}

Green tourism refers to tourism activities that can be maintained or sustained, indefinitely in their social, economic, cultural and environmental contexts sustainable tourism (UNWTO, 2015). Lipman (2011) said that green tourism paradigm has shift to embrace all nations towards unballance benefit of tourism throught optimization the potential of travelism, hence give more benefit to the community and universe, as cited below;

“...The rapidly evolving green growth paradigm shift that all nations are embracing at a policy level, with the buy-in of industry and civil society, provides an unparalleled opportunity to leverage the massive socioeconomic power of travelism (travel and tourism) to benefit humanity and the planet..." (Lipman, 2011: 29).

Green Tourism Business Scheme Program (GTBS) is one of the green tourism programs which has implemented the green tourism concept as reference to maintain sustainability of tourism development (GTBS):

(http://www.thetravelfoundation.org.uk/image s/media/Research -

_Green_Certification_Schemes.pdf

a. Compulsory: compliance with environmental legislation and a commitment to continue in improving environmental performance.

b. Management and Marketing: demonstrating good environmental management, including staff awareness, specialist training, monitoring and record keeping.

c. Social Involvement and Communication of the environmental actions to customers through range of actions, e.g. green policy; 
promotion of environmental efforts on the website, education and community as well as social projects.

d. Energy: efficiency of energy such as lighting, heating and appliance, insulation and renewable energy use.

e. Water Efficiency: e.g. good maintenance, low-consumption appliances, flush offset, rainwater harvesting as well as using ecocleaner.

f. Purchasing environmentally friendly goods and services, e.g. product made from recycled materials, use and promotion of local food and drink.

g. Waste minimization: by encouraging the 'eliminate, reduce, reuse, and recycle' principles, e.g. glass, paper, card, plastic and metal recycling: supplier take back agreements, doing systems and composting.

h. Transport: aims to minimize visitors' car use by promoting local and national public transport services, cycle hire, local walking and cycling option, and use of alternative.

i. Natural and cultural heritage: aims to increase biodiversity, e.g. wildlife, gardening, growing native species, nesting boxes as well as providing information for visitors on the wildlife on and around the site.

j. Innovation: any good and best practice actions to increase a business's sustainability that are not covered else where.

\section{Green hotel}

Green hotels is model of hotel managemnet which give more focus on environmental protection and preservation of cultural heritage which result in minimum impact on environmental degradation as well as social and culture of the local community through implementation of integrated efficiency programs as follows; energy and water efficiency, waste management and recycling programs, preservation of cultural heritage, implementing programs in reducing global warming and climate change in order to save our planet .

Schianzetz et al. (2007) reveals that in achieving sustainable development requiries three pilars namely environmental protection, social development, and economic development, as cited below:

“ ... Achieving sustainable development requires the advancement and strengthening of its three interdependent and mutually reinforcing of three pillars: environmental protection, social development, and economic development ..." Schianzetz et al (2007: 15)

In adiition, Baker (2008) says that the benefit of green hotel in the hotel operational are (i) cost efficiency (reducing operational cost from energy and water as well as efficiency from recycle program (ii) environmental protection through implementation of waste management by using recycle materials, (iii) improve addedvalue, (iv) increase market share and gaining competitive positioning, (v) improve external demand, (vi) improve customer satisfaction and guests loyalty (vii) staff motivation, (viii) cultural heritage preservation, (ix) reduce climate change and $(\mathrm{x})$ sustainable hotel.

International organization called International Tourism Partnership (ITP) is an organization which has a role in assisting tourism companies in implementing sustainable tourism through programs which is based on the green tourism concept. ITP uses "going green" as branding to strengthen its program (Baker, 2008). Specifically, it uses three pilars, namely (a) environmental protection approach, (b) Social and culture preservation approach, and (c) Economic approach.

Tourism industry is highly growing consumption of energy in the industry which has implication on the global warming and climate change. Its long term impacts will hamper the future development of tourism industry itself. As UNEP (2011) reported that:

“...The tourism sector's growing consumption of energy, especially in travel and accommodation, and its dependence on fossil fuels has important implications for global Green House Gas emissions and climate change as well as for future business growth..." (UNEP, 2011: 417). 
Gössling (2001) reveals that tourism is one of the contributors for global warming due to green house gas emision in the tourism industry. About $3.2 \%$ of the global energy have been used for tourism activities, such as traveling from one destination to the other destinations, accommodation and other activities in the destination. About 5,3\% of the total Carbon Dioxide in the air are affected by tourism activities and nearly $94 \%$ of the emition are from travelimg by using aeroplane and other types of transportations.

Impact of climate change will be on the quality of environment and the community, such as increase in air temperature, sea level, tempeature of the sea which will threaten coral reef and the plancton, decrease in rainfall. The impacts will be on drought, water supply, landslide as well as flood which are potentially threaten economic development and social and political stability, as cited in Gössling (2001) as follow:

“... Human-induced changes in the global climate system and in stratospheric ozone pose a range of severe health risks and potentially threaten economic development and social and political stability..." (Gössling, 2001:430-453).

If these situations happen in the long period of time and can not be controlled, it will threaten preservation of the natural resource. Bali has limited natural resources for sustainable development. Hence, managing environment in destination is very important. Green hotel concept is crucial to be implemented which means that environmental management need to give more attention on conservation and preservation which will contribute to the reduction on the global warming and climate change. In this case, green economy concept is one of the solution which can be implemented to make long term development of tourism, which is concists of: (i) operational cost efficiency; (ii) increase market share and competitive positioning; (iii) improve demand; and (iv) improve satifaction and guests' loyalty. Meanwhile, the social benefit result in decrease in social impact of tourism and preservation of cultural heritage which will give more benefit to the local community.

In this study, the concept of green

http://ojs.unud.ac.id/index.php/eot economy is implemented in the case of tourism accommodation in Bali which is called green tourism. According to Baker (2008) green hotel is hotel management model which is concerned with environmental protection and cultural preservation which leads to minimization impact on the environment degradation as well as social and culture of the community through implementation of integrated programs, such as energy and water efficiency, waste and recycling programs, minimization of global warming and support every program in reducing the impact of climate change. In term of social impact of tourism development on the community, the program should be able to pay attention on the local community welfare through CSR (Corporate Social Responsibility).

\section{Structural Equation Modeling (SEM)}

Structural equation modeling (SEM) is a statistical technique for building and testing statistical models, which are often causal models. It is a hybrid technique that encompasses aspects of confirmatory factor analysis, path analysis and regression, which can be seen as special cases of SEM (Pearl, 2000).

Ghozali (2008) defines Structural Equation Modeling (SEM) as a method of statistical analysis to test and estimate the causal relationship between several variables using a combination of statistical data or data that assumes a causal relationship qualitatively. Bade on the calculus aaproach, he defines SEM as:

“... Structural Equation Modeling (SEM) is a statistical technique for testing and estimating causal relationship using a combination of statistical data and qualitative causal assumption ..." (Ghozali, 2008)

Moreover, Ghozali (2008) reveals that SEM is a combination of the two methods of statistical analysis of the factor analysis developed in psychology and psychometrics and simultaneous equation modeling developed in econometrics. John (2002) argue SEM as simulateous equation models are multivariate regression models, but unlike in the multivariate model is simple where the 
response variable of the equation appears as a predictor in the equation the other, which will take effect on a reciprocal basis, either directly or against another variable that serves as an intermediary. This shows the reciprocal relationship between the variables in a model.

Characteristics SEM is (i) to distinguish explicitly between the latent variables and variables measured so that it can be used to test various hypotheses, (ii) not only for nonexperimental (correlation), but also data of the experiment, (iii) basic statistics in the SEM is the covariance, but can also use other standard statistical procedures such as regression, correlation, factor analysis and ANOVA, and (iv) SEM is an analytical technique with large samples (Morriso, 1990).

Some aspects that distinguish SEM with other multivariate analysis are (i) the SEM approach is more confirmatory rather than exploratory. However, it is possible that aspects exploratorynya can also be performed, (ii) SEM can be used to assess intervariabel relationship for the purpose of inferential data analysis. By contrast, most other multivariate procedures essentially descriptive thus testing the hypothesis becomes difficult, (iii) Other multivariate approaches are not able to assess and correct for measurement error, while the SEM is able to estimate the parameters explicitly, (iv) The only other multivariate techniques based on variables that were stretching observation alone, while the SEM technique can perform both an immeasurable variables (called latent variables) and variables measured, (v) SEM method can explain the variable immeasurable (latent variables / unobserved variables) into variable measured by the manifest variables is often called indicator so that research related to the latent variable can be done. This uniqueness makes SEM method is very popular as a research methodology in nonexperimental.

\section{Research Method}

\section{Research location and time}

Research was undertaken in DKP hotel which is located in Kuta, Bali. The hotel was choosen because DKP hotel is one of the hotels in Bali that has implemented the concept of green hotel in the hotel operational and was awarded as Green Hotel Award in the year of 2010. Research was undertaken in the periods of April-June 2011.

\section{Sample design and respondents}

Sample was designed based on the minimum criteria in implementation Structural Equation Modelling (SEM), that is 10 times the number of indicators. In this research, the number of indicators were 9 , hence the minimum sample must be 90 respondents. Regarding this research, the number of respondents who were willing to be interviewed and fill-in the questionnaires were 121. This means that, the number of sample was fulfilled the sample requirement. Respondents were guests who stay in the DKP hotel during the periods of April-June 2011.

\section{Variables and indicators}

Variables in this research consist of exogeneous and endogeneous variables. Environment and social are expressed as exogeneous variables, meanwhile economy is expressed as endogeneous variable. In addition, indicators of laten environment are energy, water and waste, indicator of laten social are employee, purchase and CSR, meanwhile indicators of laten economy are price, service and revisit (Table 1).

Table 1. Variables and indicators

\begin{tabular}{lll}
\hline \multicolumn{1}{c}{ Laten variables } & Indicators \\
\hline $\begin{array}{l}\text { Exogeneous } \\
\text { variables }\end{array}$ & \\
\hline & Environment & energy \\
\hline & & water \\
\hline & Social & waste \\
\hline & & employee \\
\hline $\begin{array}{l}\text { Endogeneous } \\
\text { variable }\end{array}$ & purchase \\
\hline & Economy & price \\
\hline & & service \\
\hline
\end{tabular}




\section{Struktural Equation Modeling}

Struktural Equation Modeling develop

in this research is as follow:

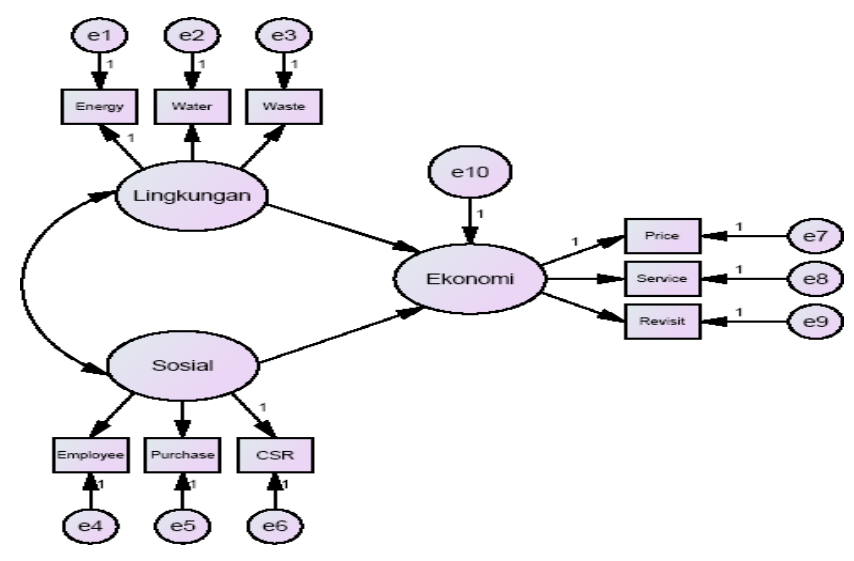

Figure 1. Structural Equation Modeling

\section{Method of data analyzis}

Respondents were interviewed based on interview guides and questionnaires. Assessing guests' perception on the green tourism applied in the DKP hotel was undertaken based on five-point Likert rating scale (Westbrook, 1980; and Colman, et. al., 1997). Relationship between variables which express level of concern of hotel management on the environment conservation, socialculture preservation and economic development were analyzed by using Software AMOS Version 23.

\section{Results and Discussion}

\section{Hotel Characteristics}

DKP hotel was built on a land area of $70,000 \mathrm{~m} 2$ which in only $32 \%$ was built and the rest $68 \%$ is open spaces including landscaping means that the hotel has already fulfil land up minimum requirement of under $40 \%$ based on the local regulation of Bali province number 16 the year of 2009 on Spatial Planning of Bali Province 2009-2029, article 122 paragraph (2) concerning: Tutorial Zoning Regulations Tourism Region, which says that basic building coefficient for each business accommodation and supporting facilities is not higher than $40 \%$. Of the total area used for open space and landscaping shows proportional ratio to provide wider

http://ojs.unud.ac.id/index.php/eot space for the development of natural vegetation. The hotel has 41 types of vegetation used in the landscaping field.

The DKP hotel has 280 rooms, 32 suites and 6 villas with average occupancy rate (guest night) per month in 2010 was 16,331 and in 2011 was 15 852, while the average occupancy rate of rooms (room occupied) in the year 2010 of $87 \%$ and year 2011 of $83 \%$. The results show a slight decrease in the average occupancy rate.

\section{Statisctical results}

\section{Feasibility of research instruments}

There are three concepts was asseessed through the indicators in this study, namely: (a) environment, (b) social, and (c) economy. The validity of each indicator in measuring each concept can be seen from the correlation, while reliability of all indicators in representing the concept measured by observing the Cronbach alpha coefficient. The following table shows the results of feasibility testing of instruments used.

Table 2. Cronbach's alpha coefficients an correlations corrected from environmental concept

\begin{tabular}{lcccc}
\hline Indicators & $\begin{array}{c}\text { Aver } \\
\text { ages }\end{array}$ & $\begin{array}{c}\text { Varian } \\
\mathrm{s}\end{array}$ & $\begin{array}{c}\text { Correla } \\
\text { tions }\end{array}$ & $\begin{array}{c}\text { Alpha } \\
\text { Cronbach } \\
\text { Coefficient } \\
\text { s }\end{array}$ \\
\hline Energy & 7.77 & 0.254 & 0.740 & 0.326 \\
\hline Water & 7.80 & 0.372 & 0.296 & 1.000 \\
\hline Waste & 7.77 & 0.254 & 0.740 & 0.326 \\
\hline $\begin{array}{l}\text { Alpha } \\
\text { Cronbach }\end{array}$ & 0.702 & & & \\
\cline { 1 - 2 } & & &
\end{tabular}

Source: processed primary data (2016).

Table 2 shows three statements that were used to measure respondents' perception regarding the environmental conditions. The statement coded by water has a correlation value of 0.296 , slightly smaller than the threshold value $(0.30)$ as a requirement for validity in assessing a concept (Chin, Marcolin and Newsted, 2003). Besides water, two other items have correlation coefficiemts exceed 0.3. Observing the correlation coefficient of water that only less than 0.004 of the threshold value, it was decided to maintain this item. All of the reliability 
indicators (Alpha Cronbach) as a reflection of the environmental concept were 0.702 , exceed the threshold value of 0.60 as a requirement for reliability in assessing a concept required by Hair et al. (1995) and Müller (2000).

Examination of the feasibility of the research instruments for the concept of social which were compossed by three indicators can be seen in the Table 3 .

Table 3. Cronbach's alpha coefficients and correlations of the social concept

\begin{tabular}{lcccc}
\hline ITEMS & $\begin{array}{c}\text { Aver } \\
\text { ages }\end{array}$ & $\begin{array}{c}\text { Varia } \\
\text { ns }\end{array}$ & $\begin{array}{c}\text { Corre } \\
\text { lation } \\
\mathrm{s}\end{array}$ & $\begin{array}{c}\text { Alpha } \\
\text { Cronbach } \\
\text { Coefficie } \\
\text { nts }\end{array}$ \\
\hline Employee & 9.50 & 0.672 & 0.724 & 0.862 \\
\hline Purchase & 9.60 & 0.593 & 0.711 & 0.884 \\
\hline CSR & 9.50 & 0.603 & 0.873 & 0.731 \\
\hline $\begin{array}{l}\text { Alpha } \\
\text { Cronbach }\end{array}$ & 0.877 & & & \\
\cline { 1 - 2 } & & & & \\
\hline
\end{tabular}

Source: processed primary data (2016)

Table 3 shows that three indicators have correlation coefficients 0.877 exceed the threshold value of 0.60 which incidate that the three indicators were valid expression of the Social concept, hence further analysis can be undertaken.

The third concept is economy as the only endogeneous concept. Results of the statistical analysis can be seen in the Table 4 .

Table 4. Cronbach's alpha coefficients and correlations of the economy concept

\begin{tabular}{lcccc}
\hline ITEMS & $\begin{array}{c}\text { Avera } \\
\text { ges }\end{array}$ & $\begin{array}{c}\text { Vari } \\
\text { ans }\end{array}$ & $\begin{array}{c}\text { Correlat } \\
\text { ions }\end{array}$ & $\begin{array}{c}\text { Alpha } \\
\text { Cronbach } \\
\text { Coefficie } \\
\text { nts }\end{array}$ \\
\hline Price & 9.53 & $\begin{array}{c}0.5 \\
33\end{array}$ & 0.571 & 0.621 \\
\hline Service & 9.67 & $\begin{array}{c}0.3 \\
68\end{array}$ & 0.559 & 0.550 \\
\hline Revisit & 9.73 & $\begin{array}{c}0.3 \\
40\end{array}$ & 0.508 & 0.649 \\
\hline $\begin{array}{l}\text { Alpha } \\
\text { Cronbach }\end{array}$ & 0.699 & & & \\
\cline { 1 - 2 } & & & &
\end{tabular}

Source: processed primary data (2016)
Table 4 shows that all of three economy indicators have correlation coefficiens more than the threshold value of 0.30 as well as Alpha Cronbach coefficient exceed the threshold value of 0.60 . The results indidicate that all indicator were valid and reliable in expressing the economy concept. Summary of the validity and reliability can be seen in the Table 5 .

Table 5. Summary of the validity and reliability

\begin{tabular}{lcccc}
\hline \multirow{2}{*}{ Variables } & \multicolumn{3}{c}{$\begin{array}{c}\text { Number of measuring } \\
\text { indicators }\end{array}$} & $\begin{array}{c}\text { Final Alpha } \\
\text { Cronbach }\end{array}$ \\
\cline { 2 - 4 } & early & invalid & used & \\
\hline Environment & 3 & 0 & 3 & 0.702 \\
\hline Social & 3 & 0 & 3 & 0.877 \\
\hline Economy & 3 & 0 & 3 & 0.699 \\
\hline
\end{tabular}

Source: processed primary data (2016)

As can be seen in the Figure 1 shows Structural Modeling which was analyzed by using AMOS program version 23. Environment and Social variables are exogeneous variables meanwhile economy variable is endogeneous variable. Structural equation model developed in this study shows correlation relationship between environment and social variables. In fact, structural equation Model was composed by two aubmodel, namely: (a) outer or measurement model, which depicts relationship between one laten with its indicators, and (b) inner or structural model, which depicts relationship between laten variables and the model (Jarvis, MacKenzie and Podsakoff, 2003; Tenenhaus et al., 2005; Henseler, Ringle and Sinkovics, 2009). Before undertaking research on the inner or structural model, the analyzis muct be undertaken on the outer or measurement model of the designed structural equation model. Results of each analyzis are as follows:

\section{Measurement model}

Outer or measurement model analyzis focuses on the analyzis between laten variable and its constituent variables. In reflexive variables, estimates variables can be seen from regression weight value. Concerning the method used in the structural equation modeling (SEM) based covariance, hence there will be one trivial indicator, which means that regeression coefficient and its level 
of significant can not be calculated. Table 6 shows the regression weight for each laten towards corresponding indicators.

Table 6. Regression weight of each laten toward indicators

\begin{tabular}{llcccc}
\hline \multirow{2}{*}{$\begin{array}{c}\text { Laten } \\
\text { varia } \\
\text { bles }\end{array}$} & Indicators & $\begin{array}{c}\text { Estim } \\
\text { ates }\end{array}$ & $\begin{array}{c}\text { Stand. } \\
\text { Error }\end{array}$ & $\begin{array}{c}\text { Critica } \\
\text { 1 Ratio }\end{array}$ & $\begin{array}{c}\text { p- } \\
\text { value }\end{array}$ \\
\hline \multirow{2}{*}{$\begin{array}{l}\text { Envir } \\
\text { onme } \\
\text { nt }\end{array}$} & Energy & 1.000 & & & \\
\cline { 2 - 6 } & Water & 0.594 & 0.084 & 7.11 & $* * *$ \\
\hline \multirow{2}{*}{$\begin{array}{l}\text { Socia } \\
1\end{array}$} & Waste & 0.811 & 0.036 & 22.51 & $* * *$ \\
\cline { 2 - 6 } & Purployee & 0.724 & 0.076 & 9.55 & $* * *$ \\
\hline \multirow{2}{*}{$\begin{array}{l}\text { Econ } \\
\text { omy }\end{array}$} & CSR & 0.866 & 0.074 & 11.66 & $* * *$ \\
\cline { 2 - 6 } & Price & 1.000 & & & $* * *$ \\
\cline { 2 - 6 } & Service & 1.165 & 0.077 & 15.14 & $* * *$ \\
\hline
\end{tabular}

Source: processed primary data (2016).

Table 6 shows that all of the regression weight as reflection of each laten to the indicators were significant at the test level $\alpha=1$ percent

\section{Structural Model}

Inner or structural model was focussed on the relationship between latens. Results can be seen from the Figur 2. Values of path coefficients are as follows:

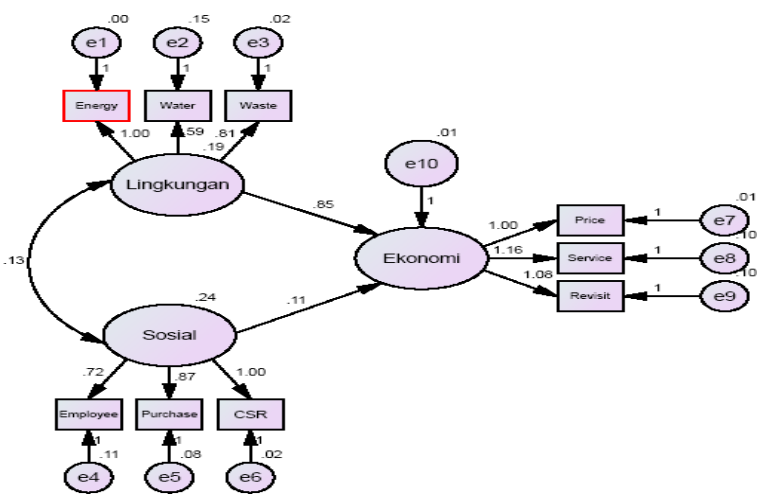

Figur 2. Analysis result of the Structural Equation Modeling based on AMOS version 23

\section{Correlation between environment and social}

Figur 1 shows correlation between laten environment and social. The statistical results show that correlation between latens is 0.128 with standard deviation 0.024 and $\mathrm{t}$ statistical $=5.431$. The result indicates that correlation coefficient is significant at the significant level of 1 percent.

\section{Causal relationship between environment, social to economy}

Figur 1 shows two causal relationship between laten variables environment and social as exogeneous variables with the laten variable economy. Analysis results of the causal relationship and the significan level can be seen from Table 7 .

Table 7. Causal relationship between exogeneous and endegenous variables to the Structural Model

\begin{tabular}{|c|c|c|c|c|c|}
\hline $\begin{array}{l}\text { Exogeneous } \\
\text { Endogeneous } \\
\text { variables } \\
\text { variable }\end{array}$ & $\begin{array}{l}\text { Esti } \\
\text { mate } \\
\mathrm{s}\end{array}$ & $\begin{array}{c}\text { Standard } \\
\text { Deviatio } \\
n\end{array}$ & $\begin{array}{r}\mathrm{t}- \\
\text { stat } \\
\text { isti } \\
\mathrm{c}\end{array}$ & \multicolumn{2}{|c|}{ p-value } \\
\hline Environment & 0.849 & 0.050 & $\begin{array}{c}17 . \\
017\end{array}$ & 0.000 & $\begin{array}{r}* * \\
*\end{array}$ \\
\hline Social & 0.114 & 0.043 & $\begin{array}{l}2.6 \\
63\end{array}$ & 0.008 & $\begin{array}{r}* * \\
*\end{array}$ \\
\hline Mark : $* * *$ & $\begin{array}{l}\text { means } \\
\text { percent. }\end{array}$ & significant & 1 & el of & 1 \\
\hline
\end{tabular}

Source: processed primary data (2016).

Table 4.6 shows the influence of both laten variables environment and social to the laten economy were significant. Laten variable environment proven to provide more dominant influence compare with the influence of laten variable social to the laten variable economy.

\section{Feasibility of Structural Equation Model}

Feasibility of structural equation model with covariance basis is assessed based on Root Mean-square of Residual (RMR) and Goodness of Fit Index (GFI) (Fornell and 
Larcker, 1981; Chin, Marcolin and Newsted, 2003; Henseler, Ringle and Sinkovics, 2009; Hair et al., 2010). The results show that $\mathrm{RMR}=0.027(<0.05)$ which indicates that minimum threshold value is acceptable. In addition, the value of GFI show that the compossed model can explain that linkages (relationship) between variables in a high percentage (81.9\%). Results indicate tha further analysis can be undertaken

\section{Discussion}

The results show that assessment of guests perception in implementation of green hotel in the hotel operational through conservation of environment and preserving social-culture and its impact on economis development was positip and has resulted in supporting sustainable tourism. Implementation of energy and water efficiencies, waste management and CSR programs are as follow:

\section{Energy efficiency}

Energy efficiency has been implemented through energy efficiency campaign either technological development or the use of eqipment, such as: (i) installation of thermostat in each room, (ii) installation of temperature control, and (iii) self-solar collector installation are in progress. Technologically, the hotel has implemented fuel energy efficiency through implementation of renewable energy by (i) modify steam boiler to become direct hot water boiler, and (ii) the use of solar water heater since 2007. Furthermore, since 2010, DKP hotel has implemented heat pump system. By implemented this kind of technology, the hotel has converged the use of diesel fuel to become electric energy which will not have exhaust gas that can result in air contamination. This means that DKP hotel has participated in reducing emission to the air program.

The important of better understanding regarding green house gas emission to the hotel staf that tourism is the bigest contributor the emission will bring about the awareness to all of the hotel management and staf to implement the green hotel to enhance sustainable hotel as revealed by Mill and
Morisson (2009) that dependency of tourism on fossil fuel energy has resulted in increasing the use of fossil fuel which will impact in the increasing concentration of green house gas in the atmosphere which will bring about increase in the earth' temperature as the main cause of climate change. Climate change is the main concern faced by all nations in the world due to its impact on rising the sea levels, changes in precipitation, ecosystem degradation, floods and landslides and other natural disasters (Baker, 2008; Mill and Morisson, 2009). Tourism will face huge threats if climate change happen in tourism destination. The economic impact of tourism which was developed in long time periods will destroy quickly becau of the climate change.

\section{Water treatment}

The main source of water used of DKP hotel is 'PDAM' and underground water. The hotel use rainwater in order to limit the use of underground water by making observed rainwater tank. This effor has also been used to avoid puddle in the hotel area. Since 2010, DKP hotel has used rain harvesting system. Installation of rain harvest system was in progress when the research was undertaken in the hotel. To conserve water use, the hotel is using equipment that can control water saving, such as water tap otomatis, urinal otomatis, dual flush toilet, water reducer di shower head, low flow faucet, low flow shower head, toilet and urinal efficienc. The hotel also use water sprinkler system dengan with timer and wheater sensor in order to control water efficiency. The hotel is also implement recycling water system by installation of hydroflow.

\section{Waste Management}

The DKP hotel has implemented 5R (Reduce, Reuse, Recycle, Replace \& Repair) through activities in the operational hotel. Waste management and recycling program has been undertaken in a special room called green recycling room to separate between solid waste which are made from papers, plastic, etc. eanwhile, management of liquid has been undertaken through Sewage Treatment Plant) which was collaborated with the company PT. Surya Tirta Buana. 


\section{Willingness to social welfare}

One indicators of economic development is the extent to which economic activity can provide benefits to the local community. The result show that DKP hotel mostly employ local people. About $82 \%$ staf are Balinese (288 people) of the total staf (353 people), about $17.3 \%$ ( 61 people) are Indonesian which are not Balinese and only $1 \%$ (4 people) are foreign employees. Even though most of the staf are Balinese, the top management are foreigners. This condition is challanging for the local people to improve ability and skill to compete the reach better position in tourism management. The more local people have better position in the hotel management the more direct effect of tourism for Bali will be.

\section{Willingness to social culture and the community}

Willingness to social culture and the community can be seen from the ability of the DKP hotel management in serving varieties of typical Balinese ornamens around the hotel, such as traditional netting equipment in the hotel' lobby which is doing by Balinese woman, traditional Balinese corner as well as traditional Balinese garden around the hotel. Willingness of hotel management to the social community can be seen from the hotel program on CSR (Corporate Social Responsibility), as follow: (i) Contribute to the "Sewaka Darma Foundation" by giving 8 cows to be breeding program the rural community of Peguyangan kaja, (ii) Contribute 30 cows to rural community Sulangi village, (iii) Contribute to reconstruction of Taman Patirtan Sudhamala temple in Klungkung regency, (iv) Contribute on education program through collaboration with the ROLE foundation.

Implementation of green hotel in operational of the hotel is in line with the Balinese philosophy called 'Tri Hita Karana' which is referred to balance and harmonious relationship between staf, management and guests in conserving the hotel environment as well as in preserving social and culture which will result in optimum impact to the economic development either to the staf, management and Bali economy as a whole. Benefit of implementation of green hotel in the operational hotel is to reduce operational cost of hotel which results in increase added-value.

\section{Conclusion}

Assessment of guests' perception in implementation of green hotel in the hotel operational through conservation of environment and preserving social-culture and its impact on economis development was positip and has resulted in supporting sustainable tourism. Environmental conservation awarenesss has been implemented through energy and water efficiency, waste management has been applied by implementing reuse and recycle programs. Social concern has been undertaken through CSR programs.

\section{Limitation}

This study was limited by the condition that in accessing economic development of the hotel as really difficult to gain exact data regarding the cash flow of the hotel due to confidential rule that has been implemented in the hotel. However, positip impact for deveopment of tourism was accessed through average occupancy of guests in the hotel.

\section{References}

Baker, C. (2008) 'Environmental Management for Hotels: The Industry Guide to Sustainable Operation', in. international Business Leaders Forum.

Chin, W. W., Marcolin, B. L. and Newsted, P. R. (2003) 'A partial least squares latent variable modeling approach for measuring interaction effects: Results from a Monte Carlo simulation study and an electronic-mail emotion/adoption study', Information systems research. INFORMS, 14(2), pp. 189-217.

Erawan, I. N. (1994) Pariwisata dan pembangunan ekonomi: Bali sebagai kasus. Upada Sastra. 
Fornell, C. and Larcker, D. F. (1981) 'Evaluating structural equation models with unobservable variables and measurement error', Journal of marketing research. JSTOR, pp. 3950.

Fridgen, J. D. (1996) 'Dimensions of tourism, educational institute book: Langsing, Michigan'.

Fyall, A. and Garrod, B. (2005) 'From competition to collaboration in the tourism industry', in G W. F. Theobald (ed.) Global tourism. Amsterdam: Elsevier, pp. 52-74.

Ghozali, I. (2008) Model persamaan struktural: Konsep dan aplikasi dengan program AMOS 16.0. Badan Penerbit Universitas Diponegoro.

Gössling, S. (2001) 'Tourism, economic transition and ecosystem degradation: interacting processes in a Tanzanian coastal community', Tourism Geographies. Taylor \& Francis, 3(4), pp. 430-453.

Hair, J. F., Anderson, R. E., Tatham, R. L. and Black, W. C. (1995) 'Multivariate Data Analysis with Readings, Prentice Hall Englewood Cliffs', NJ Google Scholar.

Hair, J. F. J., Black, W. C., Babin, B. J. and Anderson, R. E. (2010) 'Multivariate Data Analysis Seventh Edition Prentice Hall'.

Henseler, J., Ringle, C. M. and Sinkovics, R. R. (2009) 'The use of partial least squares path modeling in international marketing', in New challenges to international marketing. Emerald Group Publishing Limited, pp. 277319.

Jarvis, C. B., MacKenzie, S. B. and Podsakoff, P. M. (2003) 'A critical review of construct indicators and measurement model misspecification in marketing and consumer research', Journal of consumer research. Oxford University Press, 30(2), pp. 199-218.
Lipman, G. (2011) 'tourism \& travel: IN THE GREEN ECONOMY', in International Trade Forum. International Trade Centre, p. 28.

Mendiratta, A. (2012) Come Closer: How Tourism is Shaping the Future of Nations. BookBaby.

Mill, R. C. and Morisson, A. M. (2009) The Tourism System. The United States of America: Kendall Hunt Publising Company.

Morriso, D. (1990) Multivariate Statistical Methods. Third Edition. McGraw-Hill Publishing Company.

Müller, F. G. (2000) 'Ecotourism: an economic concept for ecological sustainable tourism', The International Journal of Environmental Studies. Taylor \& Francis, 57(3), pp. 241-251.

Tenenhaus, M., Vinzi, V. E., Chatelin, Y.-M. and Lauro, C. (2005) 'PLS path modeling', Computational statistics \& data analysis. Elsevier, 48(1), pp. 159-205.

UNEP (2011) 'Green Economy. Tourism Investing in Energy and Resource Efficiency'.

UNWTO (2015) UNWTO/UNESCO World Conference on Tourism and Culture gathers Ministers of Tourism and Culture for the first time (Press Release) -and-culture-gathersministers-tourism-. Available at: http://media.unwto.org/pressrelease/2015-02-06/unwtounescoworld-conference-tourism. 